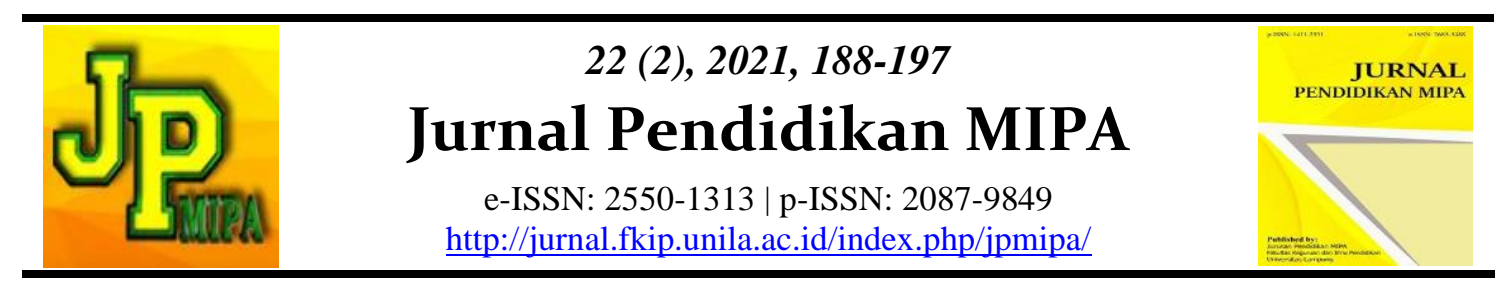

\title{
Learning Amid The Covid-19 Pandemic: What is The Attitude Towards Science of Middle School Students?
}

\author{
Heri Setiawan*, Andi Suhandi, Diana Rochintaniawati
}

Department of Natural Science Education, Universitas Pendidikan Indonesia, Indonesia

\begin{abstract}
This article aims to find out the attitude toward science of students during online learning in the midst of the Covid-19 pandemic which is reviewed based on the TOSRA indicator. The method used in this study is a descriptive method. The sample used in the study amounted to 55 students of MTs Negeri 2 Bolaang Mongondow. The study was conducted by spreading the 4point science attitude scale instrument to students as many as 20 statement items. The results showed that the indicators enjoyment of science lessons, leisure interest in science, further study in the field of science, and career interest in science got an average score of 77.38 in the excellent category, 74.54 in the high category, 68.36 in the high category, and 65.72 in the high category. While the overall average value at 71.38 is in the high category. Thus, it can be concluded that the attitude toward science of students in the midst of the covid-19 pandemic is in a good category. The results also showed that the TOSRA indicator is effectively used to measure students' attitudes toward science.
\end{abstract}

Keyword: learning in a time of pandemic, distance learning, attitude toward science.

Abstrak: Artikel ini bertujuan untuk mengetahui attitude toward science siswa selama pembelajaran daring di tengah pandemi Covid-19 yang ditinjau berdasarkan indikator TOSRA. Metode yang digunakan dalam penelitian ini adalah metode deskriptif. Sampel yang digunakan dalam penelitian berjumlah 55 siswa MTs Negeri 2 Bolaang Mongondow. Penelitian dilakukan dengan menyebarkan instrumen science attitude scale skala 4-poin kepada siswa sebanyak 20 item pernyataan. Hasil penelitian menunjukan bahwa indikator Enjoyment of science lessons, Leisure interest in science, Further study in the field of science, dan Career interest in science mendapatkan rata-rata skor secara berturut-turut 77,38 pada kategori sangat baik, 74,54 pada kategori tinggi, 68,36 pada kategori tinggi, dan 65,72 pada kategori tinggi. Sedangkan nilai ratarata keseluruhan di dapat 71,38 berada pada kategori tinggi. Sehingga dengan demikian, dapat disimpulkan bahwa attitude toward science siswa di tengah pandemi covid-19 berada dalam kategori baik. Hasil penelitian juga menunjukan bahwa indikator TOSRA efektif digunakan untuk mengukur attitude toward science siswa.

Kata kunci: belajar di masa pandemi, pembelajaran jarak jauh, attitude toward science.

Heri Setiawan et al.

Email: herisetiawan@upi.edu
DOI: http://dx.doi.org/10.23960/jpmipa/v22i2.pp188-197

Received: 18 November 2021

Accepted: 15 December 2021 


\section{- INTRODUCTION}

The year 2019 is the beginning of the emergence of the COVID-19 outbreak (Corona Virus Disease-2019). The outbreak is the result of SARS Cov-2 (Cucinotta \& Vanelli, 2020; Dhama et al., 2020). Considering the global threat, WHO as the world health agency declares COVID-19 as a public health emergency of concern to the world (H. Li et al., 2020). In line with this, WHO also declared the coronavirus as a pandemic on March 11, 2020, because of its impact affecting various sectors of life in the world (G. H.-Y. Li et al., 2021; Blake et al., 2021). The impact of the pandemic in addition to the economic sector, also affects the education sector such as school closures (Munastiwi \& Puryono, 2021; Golberstein et al., 2020). As a result, the learning process becomes disrupted and results in changes in teaching strategies. Various new methods in learning have emerged one of them such as the transmission of material information over the web (Ansong-Gyimah, 2020; Reddy et al., 2020). The existence of a pandemic outbreak does not mean the learning process must be stopped, the learning process must continue to be implemented because education is a place to form the character of a competitive student.

The role of the government in this is certainly very important. To prevent the expansion of the covid-19 outbreak, Indonesia has implemented policies since 2020 in the form of distance restrictions for the enactment of physical distancing and social distancing. Similar policies are also in place around the world to lower the infection curve (Blake et al., 2021; Golberstein et al., 2020; Wang et al., 2020). In the field of education, the ministry of education and culture in Indonesia issued SE No. 15 of 2020 on the implementation of learning conducted from home or distance learning in times of emergency due to covid-19 (Winata et al, 2021). Distance learning is one of the solutions so that the learning process can continue (Golberstein et al., 2020; Wang et al., 2020). Not only is Indonesia is facing a changing situation in the country but the UK is also rapidly turning to online learning that has begun in March 2020 (Blake et al., 2021).

The disrupted learning process due to the covid-19 outbreak will certainly have an impact on students' cognitive and affective abilities (Winata et al, 2021). The creativity of a teacher is needed today. The online learning process or PJJ will not work if there is no role from an educator (Joshi et al., 2020). Therefore, with the integration of technology in online learning a teacher is required to master technology. The development of technology today encourage to create of various innovations in learning. The existence of Technology in IPA learning can simulate natural phenomena that students did not previously get when learning through books, such as animation and virtual practicums. Learning resources during the current pandemic are very varied, such as the use of emodules, presentation of materials through zoom meetings, utilization of YouTube, and virtual lab practicum. For now, the most widely used material delivery medium worldwide is e-learning (Johnson et al., 2021; Bhuvaneswari \& Dharanipriya, 2020). This allows it to affect the cognitive and affective dimensions of students.

Attitudes are very important for students, especially attitudes towards IPA lessons (Sharma et al., 2021; Hong et al., 2008; Ellis, 1993; Simpson \& Oliver, 1990; Osborne \& Collins, 2000). According to Oliver \& Simpson (1988) attitude toward science (ATS) is defined as the extent to which a person likes science. Furthermore, Osborne et al (2003) define that ATS represents students' good or bad perception of science, when they are subjects in school and in the community. In addition, one of the important parts in improving learning achievement (Beaton, 1996) and shaping the character of students it to scientific thinking is a good ATS (Fadhil et al., 2015). Thus it can be interpreted that ATS is an expression that is shown as an embodiment of likes or dislikes about an object 
about science. When students have a good attitude, it will indirectly affect their science learning achievement (Germann, 1988; Oliver \& Simpson, 1988). Similarly, Barmby et al (2008) found that the attitude toward a science of students in junior high school may influence their participation rate in science in the future. A student who likes science will be easier to understand science so that it will have an impact on his learning achievement (Hsu et al, 2019). Conversely, students' bad attitude towards science will affect their low understanding of science.

Online learning allows students to change students' attitudes towards science, whether attitudes are better or vice versa. Therefore, to find out attitude toward science students in pandemic times, formulated problems in this study about how the attitude toward science students MTs N 2 Bolaang mongondow in the pandemic period. The research was conducted aimed at knowing the ATS students of MTs during the learning process conducted online using the instrument Test of Science Related Attitude (TOSRA) which consists of; 1) Enjoyment of science lessons, 2) Leisure interest in science, 3) Further study in the field of science, and 4) Career interest in science (Fraser, 1981).

\section{- METHOD}

This study uses descriptive methods conducted in MTs N 2 Bolaang Mongondow, north Sulawesi province, Indonesia. Respondents in the study numbered 55 people consisting of 18 students of class VII, 19 students of class VIII, and 18 students IX.

Sampling is done using simple random sampling techniques. This technique can be used when the sample taken in a population is homogeneous. The population in this study amounted to 230 students, but in this study the sample to be used was as many as 55 students. If the population or sample in the study is in large quantities, then the sample can be taken $15-25 \%$ Arikunto (2008).

The data in this study was obtained directly from the research subjects. The research was conducted by spreading the instrument science attitude scale (SAS) reviewed from the TOSRA indicator through google form that can be directly filled out by students who have links. TOSRA indicatother has the effectiveness to measure attitude toward science reinforced by the validation of research that has been done (Anwer et al., 2012; Khalili, 1987; Schibeci \& McGaw, 1981; Stolarchuk \& Fisher, 2001). The attitude scale instrument consists of 20 statement items. The validity of the instrument is guaranteed by validating to the relevant expert. Table 1 shows the number of SAS items per indicator.

Table 1. Number of statements per indicator

\begin{tabular}{lllc}
\hline No & \multicolumn{1}{c}{ Dimension } & \multicolumn{1}{c}{ Instrument } & $\begin{array}{c}\text { Number of } \\
\text { questions }\end{array}$ \\
\hline 1 & Enjoyment of science lessons & science attitude scale & 5 item \\
\hline 2 & Leisure interest in science & science attitude scale & 5 item \\
\hline 3 & Further study in the field of science & science attitude scale & 5 item \\
\hline 4 & Career interest in science & science attitude scale & 5 item \\
\hline
\end{tabular}

The statement that will be submitted to students is a type of science attitude scale instrument. The response that has been obtained from students will be processed and presented in the form of tables. By using SAS attitude toward science instruments students can be measured appropriately (Anwar \& Bhutta, 2014). Attitude scale assessment techniques in this study used a scale of 4, 3, 2, 1 (Strongly Agree, Agree, Disagree, Strongly Disagree). Before interpreting the data, the student's ATS average 
score is sought with the calculation of overall score divided by the maximum score, then multiplied by $100 \%$.

As for looking at the average criteria of student attitude categories on each indicator, it can be seen based on criteria with grades $0-25$ is a very low category, 26-50 low category, 51-75 high category, and 76-100 is an excellent or high category (Sinaga, 2017).

\section{- RESULT AND DISCUSSION}

At the time of the learning pandemic is still implemented, one of the efforts made by the government is to implement online learning policies throughout the region. The deployment of the SAS instrument aims to find out whether attitude toward science MTs $\mathrm{N} 2$ bolaang mongondow students during pandemic times get better or vice versa. After data analysis, the average ATS value of students during online study is described as in table 2 .

Table 2. Average ATS score of each indicator

\begin{tabular}{llcc}
\hline No & \multicolumn{1}{c}{ Indicator } & $\begin{array}{c}\text { Average Score } \\
(\mathbf{\%})\end{array}$ & Category \\
\hline 1 & Enjoyment of science lessons & 77.38 & Excellent \\
\hline 2 & Leisure interest in science & 74.54 & High \\
\hline 3 & Further study in the field of science & 68.36 & High \\
\hline 4 & Career interest in science & 65.72 & High \\
\hline & Overall average score & 71.38 & High \\
\hline
\end{tabular}

The magnitude of achievement of students' attitude toward science scores during the current pandemic is $71.38 \%$ which is in a very high or very good category after being interpreted based on the criteria obtained as shown in table 2.

The graph 1 shows the comparison of attitude toward science values that can be from the results of instruments shared in terms of the Enjoyment of science lessons indicator, Leisure interest in science, Further study in the field of science, and Career interest in science.

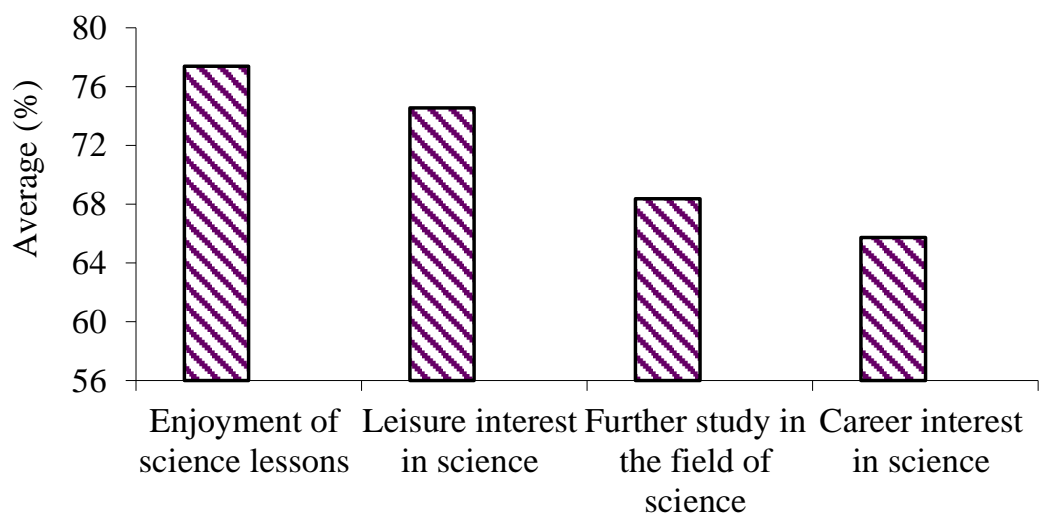

Figure 1. Average attitude toward science based on 4 indicators

\section{Indicator Enjoyment of Science Lessons}

On the enjoyment of science lessons indicator shows a positive attitude seen from the average value of 77.38 which is in the category is very good (chart 1). This shows that 
students have a sense of pleasure in science even though the learning process is done online. This is in line with what is expressed by Kurniawan et al (2019) ATS is indicated by likes or dislikes, as well as expressions of accepting or rejecting an object related to science. Students who have a sense of pleasure in science will tend to be active when science learning takes place. While students who do not like science will tend to be passive when science learning takes place. In addition, a student who likes science will be easier to understand science so that it will have an impact on his learning achievement Hsu et al (2019)

Students' pleasure in learning science is due to several factors such as the use of learning resources and the way teachers teach. Learning in the midst of the current pandemic, technology is very important to be integrated as a more flexible learning method and encourage students to have professional skills talent (Trujillo Maza et al., 2016). Based on the criteria obtained, it is known that the use of learning resources in MTs N 2 Bolaang mongondow is good so that it triggers a good student attitude towards science. The use of learning resources and the way teachers present learning materials will certainly support a fun learning process.

\section{Indicator Leisure Interest in Science}

On the Leisure interest in science indicator, you get an average value of 74.54 which is in the high or good category (chart 1). Although the average rat value on this indicator is lower than the enjoyment of science lessons indicator, students' interest in science is still relatively high. This shows that students' interest in science at MTs N 2 Bolaang Mongondow is not influenced by the learning process conducted online. Students' pleasure in learning also affects the interest in willing to learn as shown by the acquisition of average scores on indicators of interest in science. When they have a sense of pleasure in learning, it will create a pleasant learning environment so that the interest in science will also increase. Students' sense of interest in science can be seen when they tend to be more active in participating in everything related to science (Hoffler et al., 2019). With the interest of students to high science will trigger a good attitude towards science. In addition, the sense of interest can affect the attention of students so that it will also increase their intelligence (Adodo, 2013).

\section{Indicator Further Study in The Field of Science}

In the Further study indicator in the field of science, the average value is 68.36 (graph 1). The value on this indicator is lower than the indicator of pleasure in sc ience and interest in science. Although there are differences, the interest in further studies in the field of science is also still classified as a high category. This shows that students and students at MTs $2 \mathrm{~N}$ Bolaang Mongondow are more than 50\% interested in further study in the field of IPA.

Students' interest in further study in the field of IPA can be influenced by their pleasure and interest in the course of science learning. This is evidenced by the achievement of the student attitude pleasure indicator gets a very good category and on the interest indicator, the student's attitude is also relatively good. When students are interested in continuing in science, they will tend to dig into science-related information and add time to study. Thus, they will have a thought about his career in the future (Wiza et al., 2019). 


\section{Indicator Career Interest in Science}

The Career interest in science indicator shows that many of them are motivated and have an interest in a career in IPA. This is indicated by an average value of 65.72 (graph 1). Although this indicator gets the lowest average value of other indicators, the average score obtained is still in the high category. The factors that encourage students' interest in a science career are influenced by their high curiosity and ideals related to science. This is evidenced by the results of the distribution of SAS instruments on career indicators in the field of science. Fulmer (2014)states that attitudes change slowly due to internal factors of the students themselves, thus affecting all perceptions about science as well as interest in pursuing a career in science. Therefore, a good attitude towards science is needed by students. Similarly, Barmby et al (2008) found that students' attitude toward science may influence their participation rate in science in the future. It can be seen that indicators of the pleasure of studying science, interest in science, and they want to continue their studies in the field of science affect the interest of students for a career in natural science.

Based on the indicators that have been mentioned, ATS students MTs N 2 Bolaang Mongondow are in the high category. This shows that the attitude toward science of students during pandemic times is still good. With these findings, it can be seen that the current pandemic period does not affect students' attitudes towards science learning. The factors that affect the attitude of students can be reviewed from internal and external factors. Internal factors usually come from the student itself, namely related to motivation, likes, and interest in learning. When students have a good attitude toward science, it will indirectly also affect their learning achievement (Germann, 1988; Oliver \& Simpson, 1988; Bybee \& McCrae, 2011; Newell et al., 2015) as well as an interest in a career in science (Fulmer et al., 2019). Sim ilarly, Barmby et al. (2008) found that ATS students in junior high school may influence their participation rate in science in the future. A student who likes science will be easier to understand science so that it has an impact on his better learning achievement (Hsu et al, 2019). Conversely, the bad attitude that students have towards science will have an effect on understanding science and low learning achievement.

External factors that affect student ATS usually come from the environment, such as the way teachers teach even parents, making it difficult for students to do online learning. In addition, the existence of technology that has benefits in online learning, among students there are also several obstacles, including, lack of capacity of laptops, mobile phones, networks, and lack of knowledge of students in applying technology (Layali \& Al-Shlowiy, 2020; Mousavi et al., 2020; Rafiq et al., 2020). Of course, it will have an impact on student attitudes that are not good, and affect low learning achievement. The findings also show that the TOSRA instrument is effectively used to measure students' attitude toward science in the current pandemic. Research conducted by Kurniawan et al (2019) also showed that attitude toward science is reviewed from indicators contained in TOSRA is in the good category.

\section{- CONCLUSION}

From the results of data analysis that has been conducted based on the distribution of Attitude Scale instruments in MTs N 2 Bolaang Mongondow, it can be concluded that the Enjoyment of science lessons indicator with an excellent category has a percentage of 77.38. Then the Leisure interest in science indicator with a high or good category has a percentage of 74.54. Further study indicator in the field of science is in the high category 
with a percentage of 68.36. While the Career interest in science indicator with a high category has a percentage of 65.72 . The overall average score was 71.38 with a high category. Although there are significant differences from the four indicators, all are in the good category. This shows that the attitude toward science of students reviewed from 4 TOSRA indicators in MTs N 2 Bolaang Mongondow during the pandemic period is relatively good.

Advice for future research can link ATS to various cognitive dimensions, such as critical thinking, creativity, collaborative, and its ability to communicate. The researchers could also emphasize attitude toward science in students' gender types, as well as analyze whether the presence of technology can affect ats students who are in remote areas with difficult access to technology.

\section{- REFERENCES}

Arikunto S. ( 2008). Dasar-dasar Evaluasi Pendidikan [The Basics of Educational Evaluation]. Jakarta: Bumi Aksara

Adodo, S. O. (2013). Correlate of pre-service teachers and in-service teachers perceived and priorotized students' psychological profiles for the teaching and evaluating Basic Science and Technology (BST). Journal of Emerging Trends in Engineering and Applied Sciences, 4(2), 305-310.

Ansong-Gyimah, K. (2020). Students' Perceptions and Continuous Intention to Use ELearning Systems: The Case of Google Classroom. International Journal of Emerging Technologies in Learning, 15(11), 236-244.

Anwar, N. P., \& Bhutta, S. M. (2014). Students' attitude towards science in lower secondary classes : Comparison across regions. Journal of Educational Research, 17(1), 77-90. http://ecommons.aku.edu/pakistan_ied_pdck

Anwer, M., Iqbal, H. M., \& Harrison, C. (2012). Students' attitude towards science: A case of Pakistan. Pakistan Journal of Social and Clinical Psychology, 9(2), 3-9.

Barmby, P., Kind, P. M., \& Jones, K. (2008). Examining changing attitudes in secondary school science. International Journal of Science Education, 30(8), 1075-1093.

Beaton, A. E. (1996). Science Achievement in the Middle School Years. IEA's Third International Mathematics and Science Study (TIMSS). ERIC.

Bhuvaneswari, S. S. B., \& Dharanipriya, A. (2020). Attitude of UG students towards elearning. International Journal of Humanities and Social Sciences, 9(2), 35-40.

Blake, H., Knight, H., Jia, R., Corner, J., Morling, J. R., Denning, C., Ball, J. K., Bolton, K., Figueredo, G., Morris, D. E., Tighe, P., Villalon, A. M., Ayling, K., \& Vedhara, K. (2021). Students' Views towards Sars-Cov-2 Mass Asymptomatic Testing, Social Distancing and Self-Isolation in a University Setting during the COVID-19 Pandemic: A Qualitative Study. International Journal of Environmental Research and Public Health, 18(8), 4182. https://doi.org/10.3390/ijerph18084182

Bybee, R., \& McCrae, B. (2011). Scientific literacy and student attitudes: Perspectives from PISA 2006 science. International Journal of Science Education, 33(1), 7-26.

Cucinotta, D., \& Vanelli, M. (2020). WHO declares COVID-19 a pandemic. Acta Bio Medica: Atenei Parmensis, 91(1), 157.

Dhama, K., Khan, S., Tiwari, R., Sircar, S., Bhat, S., Malik, Y. S., Singh, K. P., Chaicumpa, W., Bonilla-Aldana, D. K., \& Rodriguez-Morales, A. J. (2020). Coronavirus Disease 2019-COVID-19. Clinical Microbiology Reviews, 33(4), e00028-20. https://doi.org/10.1128/CMR.00028-20

Ellis, R. S. (1993). Impacting the science attitudes of minority high school youth. School 
Science and Mathematics, 93(8), 400-407.

Fadhil, M. Y. F. Y., Azhar, A., \& Fakhruddin, F. (2015). Sikap terhadap Sains Siswa dalam Pembelajaran IPA Fisika melalui Penerapan Strategi Index Card Match pada Materi Kalor di Kelas VII 4 SMPN 20 Pekanbaru [Attitude towards Student Science in Physics IPA Learning through The Application of Index Card Match Strategy on Heat Matter in Class VII 4 SMPN 20 Pekanbaru]. Riau University.

Fraser, B. J. (1981). Tosra: Test of science-related attitudes: Handbook. Australian Council for Educational Research.

Fulmer, G. W. (2014). Undergraduates' Attitudes Toward Science and Their Epistemological Beliefs: Positive Effects of Certainty and Authority Beliefs. Journal of Science Education and Technology, 23(1), 198-206.

Fulmer, G. W., Ma, H., \& Liang, L. L. (2019). Middle school student attitudes toward science, and their relationships with instructional practices: a survey of Chinese students' preferred versus actual instruction. Asia-Pacific Science Education, 5(1), 9.

Germann, P. J. (1988). Development of the attitude toward science in school assessment and its use to investigate the relationship between science achievement and attitude toward science in school. Journal of Research in Science Teaching, 25(8), 689703.

Golberstein, E., Wen, H., \& Miller, B. F. (2020). Coronavirus disease 2019 (COVID-19) and mental health for children and adolescents. JAMA Pediatrics, 174(9), 819-820.

Herliandry, L. D., Nurhasanah, N., Suban, M. E., \& Kuswanto, H. (2020). Pembelajaran Pada Masa Pandemi Covid-19 [Learning during the Covid-19 Pandemic]. JTP Jurnal Teknologi Pendidikan, 22(1), 65-70.

Höffler, T. N., Köhler, C., \& Parchmann, I. (2019). Scientists of the future: an analysis of talented students' interests. International Journal of STEM Education, 6(1), 29.

Hong, Z., Lin, H., \& Lawrenz, F. (2008). Promoting single-parent family children's attitudes toward science and science performance through extracurricular science intervention in Taiwan. International Journal of Science Education, 30(4), 469493.

Hsu, P.-S., Lee, E. M., Ginting, S., Smith, T. J., \& Kraft, C. (2019). A case study exploring non-dominant youths' attitudes toward science through making and scientific argumentation. International Journal of Science and Mathematics Education, 17(1), 185-207.

Johnson, J. B., Reddy, P., Chand, R., \& Naiker, M. (2021). Attitudes and awareness of regional Pacific Island students towards e-learning. International Journal of Educational Technology in Higher Education, 18(1), 13.

Joshi, A., Vinay, M., \& Bhaskar, P. (2020). Impact of coronavirus pandemic on the Indian education sector: perspectives of teachers on online teaching and assessments. Interactive Technology and Smart Education.

Khalili, K. Y. (1987). A crosscultural validation of a test of science related attitudes. Journal of Research in Science Teaching, 24(2), 127-136.

Kurniawan, D. A., Astalini, A., \& Kurniawan, N. (2019). Analyzing of students'attitudes toward science on junior high school: Case Study in Muaro Jambi, Indonesia. Jurnal Pena Sains, 6(2), 69-79.

Layali, K., \& Al-Shlowiy, A. (2020). Students'perceptions of e-learning for esl/efl in saudi universities at time of coronavirus: a literature review. Indonesian EFL Journal, 6(2), 97-108. 
Li, G. H.-Y., Lam, S. K.-K., Wong, I. C.-K., Chu, J. K.-P., \& Cheung, C.-L. (2021). Education Attainment, Intelligence and COVID-19: A Mendelian Randomization Study. Journal of Clinical Medicine, 10(21), 4870. https://doi.org/10.3390/jcm10214870

Li, H., Liu, S.-M., Yu, X.-H., Tang, S.-L., \& Tang, C.-K. (2020). Coronavirus disease 2019 (COVID-19): current status and future perspectives. International Journal of Antimicrobial Agents, $55(5)$ 105951. https://doi.org/10.1016/j.ijantimicag.2020.105951

Mousavi, A., Mohammadi, A., Mojtahedzadeh, R., Shirazi, M., \& Rashidi, H. (2020). ELearning Educational Atmosphere Measure (EEAM): A New Instrument for Assessing E-Students' Perception of Educational Environment. Research in Learning Technology, 28.

Munastiwi, E., \& Puryono, S. (2021). Unprepared management decreases education performance in kindergartens during Covid-19 pandemic. Heliyon, 7(5), e07138e07138. https://doi.org/10.1016/j.heliyon.2021.e07138

Newell, A. D., Zientek, L. R., Tharp, B. Z., Vogt, G. L., \& Moreno, N. P. (2015). Students' attitudes toward science as predictors of gains on student content knowledge: Benefits of an after-school program. School Science and Mathematics, 115(5), 216-225.

Oliver, J. S., \& Simpson, R. D. (1988). Influences of attitude toward science, achievement motivation, and science self concept on achievement in science: A longitudinal study. Science Education, 72(2), 143-155.

Osborne, J., \& Collins, S. (2000). Pupils'\& parents' views of the school science curriculum. Kings College London.

Osborne, J., Simon, S., \& Collins, S. (2003). Attitudes towards science: A review of the literature and its implications. International Journal of Science Education, 25(9), 1049-1079.

Rafiq, F., Hussain, S., \& Abbas, Q. (2020). Analyzing students' attitude towards elearning: A case study in higher education in Pakistan. Pakistan Social Sciences Review, 4(1), 367-380.

Reddy, P., Sharma, B., \& Chandra, S. (2020). Student readiness and perception of tablet learning in higher education in the pacific-a case study of Fiji and Tuvalu: Tablet learning at USP. Journal of Cases on Information Technology (JCIT), 22(2), 5269.

Schibeci, R. A., \& McGaw, B. (1981). Empirical validation of the conceptual structure of a test of science-related attitudes. Educational and Psychological Measurement, 41(4), 1195-1201.

Sharma, B., Narayan, S., Khan, M. G. M., Kumar, B., Havea, R., Johnson, J. B., \& Naiker, M. (2021). The Attitudes of Tongan Senior Secondary Students Toward Science. New Zealand Journal of Educational Studies, 1-24.

Simpson, R. D., \& Oliver, J. S. (1990). A summary of major influences on attitude toward and achievement in science among adolescent students. Science Education.

Sinaga, P. (2017). Model Proses Menulis Materi Ajar Sains. bandung: Departemen Pendidikan Fisika FPMIPA UPI.

Stolarchuk, E., \& Fisher, D. (2001). An investigation of teacher-student interpersonal behavior in science classrooms using laptop computers. Journal of Educational Computing Research, 24(1), 41-55.

Wang, C., Xie, A., Wang, W., \& Wu, H. (2020). Association between medical students' 
prior experiences and perceptions of formal online education developed in response to COVID-19: a cross-sectional study in China. BMJ Open, 10(10), e041886e041886. https://doi.org/10.1136/bmjopen-2020-041886

Winata, K. A., Zaqiah, Q. Y., Supiana, S., \& Helmawati, H. (2021). Kebijakan Pendidikan Di Masa Pandemi [Education Policy in a Time of Pandemic]. Ad-ManPend: Jurnal Administrasi Manajemen Pendidikan, 4(1), 1-6.

Wiza, O. H., Dewi, U. P., \& Trismon, S. (2019). Implikasi sikap sosial, minat menambah jumlah waktu belajar, dan ketertarikan berkarir di bidang IPA [Implications of social attitudes, interests in increasing the amount of study time, and career interest in IPA]. Natural: Jurnal Ilmiah Pendidikan IPA, 6(2), 86. 